\title{
Faktor Determinan Aktivitas Kholinesterase Darah Petani Holtikultura di Kabupaten Majalengka
}

\author{
Dedi Ruhendi*
}

\begin{abstract}
Abstrak
Kholinesterase darah merupakan salah satu indikator keracunan pestisida yang masih menjadi masalah kesehatan masyarakat, khususnya diwilayah pertanian. Pada tahun 2005, di Kabupaten Majalengka, hasil pemeriksaan mendapatkan angka keracunan ringan $(21,7 \%)$ keracunan sedang $(32,5 \%)$ dan keracunan berat $(3,6 \%)$ Penelitian ini bertujuan untuk mengkaji berbagai faktor determinan aktivitas kholinesterase darah pada petani penyemprot hama tanaman holtikultura. Penelitian yang menggunakan desain potong lintang dengan sumber data sekunder hasil pemeriksaan aktivitas kholinesterase darah yang dilakukan oleh Dinas Kesehatan Kabupaten Majalengka tahun 2007. Variabel dominan yang berhubungan dengan aktivitas kholinesterase menggunakan analisis multivariat adalah riwayat terakhir menyemprot (OR=9,613,95\% Cl=2,906-31,799), memakai Alat Pelindung Diri (APD) baju lengan panjang $(\mathrm{OR}=8,872,95 \% \mathrm{Cl}=2,006-39,232)$, Mandi secara baik (OR=5,446, 95\% $\mathrm{Cl}=1,266-23,417)$, Merokok waktu menyemprot $(\mathrm{OR}=4,641,95 \% \mathrm{Cl}=1,717-12,546)$, riwayat pelatihan/penyuluhan $(\mathrm{OR}=3,217,95 \% \mathrm{Cl}=1,466-7,059)$, posisi menyemprot terhadap arah angin $(\mathrm{OR}=2,550,95 \% \mathrm{Cl} O \mathrm{R}=1,169-5,564)$ dan umur responden $(\mathrm{OR}=0,416,95 \% \mathrm{Cl} O \mathrm{R}=0,190-0,911)$. Disarankan agar setiap petani menyemprot hanya tiga minggu sekali, dengan sistem kelompok dan bergantian. Meningkatkan frekuensi pelatihan/penyuluhan bagi para petani secara terpadu di wilayah kerja puskesmas, dengan materi pokok peningkatan hidup bersih dan sehat, pajanan pestisida ke dalam tubuh manusia, penanganan pestisida, penggunaan APD dan upaya pencegahan dan penanggulangan keracunan pestisida.
\end{abstract}

Kata kunci : Kholinesterase darah, keracunan pestisida, holtikultura.

\begin{abstract}
Blood cholinesterase is an indicator of pesticide intoxication which is still a threat to public health, especially in agriculturural areas. In 2005, in Majalengka district, study found rates of mild intoxiciation (21.7\%), moderate intoxication (32.5\%), and heavy intoxication (3.6\%). This research aims at investigating determinant factors of blood cholinesterase activity among horticulture sprayer farmers. The study employed cross-sectional design with blood cholinesterase activity test results conducted by Majelengka Health Office in 2007 as secondary data. Dominant variables related to cholinesterase activity found in multivariate analysis were spraying history $(\mathrm{OR}=9.613,95 \% \mathrm{Cl}=2.906-31.799)$, using long sleeve self protective wear $(\mathrm{OR}=8.872,95 \% \mathrm{Cl}=2.006-39.232)$, proper shower ( $\mathrm{OR}=5.446,95 \% \mathrm{Cl}=1.266-23.417)$, smoking during spraying ( $\mathrm{OR}=4.641,95 \% \mathrm{Cl}=1.717-12.546)$, history of training/extension (OR=3.217, 95\% $\mathrm{Cl}=1.466-7.059)$, spraying position against wind $(\mathrm{OR}=2.550,95 \% \mathrm{Cl}=1.169-5.564)$ and age $(\mathrm{OR}=0.416,95 \% \mathrm{Cl} \mathrm{OR}=0.190-0.911)$. It is recommended to spray once in three weeks and not more, employing group work and shifting method; increasing frequency of training/extension in an integrated way within working área of Health Center by inserting materials on clean and healthy lifestyle, pesticide exposure, pesticide handling, the use of self protective wear, and prevention and handling pesticide intoxication.
\end{abstract}

Key words : Blood cholinesterase, pesticide intoxication, horticulture. 
Petani merupakan tenaga kerja informal yang sangat besar di Indonesia, sekitar 40\% dari angkatan kerja (sekitar 42 juta orang), mengakibatkan risiko terjadinya penyakit akibat kerja mudah dialami oleh petani terutama bagi mereka yang selalu berhubungan dengan bahan kimia pestisida yaitu para petani penyemprot hama. Gangguan kesehatan para petani akibat pekerjaan penyemprotan dapat terjadi keracunan bersifat akut atau mendadak yang kita kenal sebagai kecelakaan, dapat pula bersifat kronis atau menahun.

Hasil pemeriksaan aktivitas kholinesterase darah yang dilakukan di 27 Propinsi tahun 1999, menunjukkan angka $62,72 \%$ normal, $18,51 \%$ keracunan ringan, 10,49\% keracunan sedang dan 4,69\% keracunan berat. Propinsi Jawa Barat menunjukkan angka 53,53\% normal, 32,29\% keracunan ringan, 10,89\% keracunan sedang dan 3,29\% keracunan berat. Sedangkan di Kabupaten Majalengka hasil pemeriksaan kholinesterase pada tahun 2005 menunjukkan angka 42,2\% normal, $21,7 \%$ keracunan ringan, $32,5 \%$ keracunan sedang dan 3,6\% keracunan berat. ${ }^{1}$ Data tersebut menggambarkan kasus keracunan oleh pestisida para petani penyemprot hama tanaman pengguna pestisida yang masih tinggi $(57,8 \%)$. Hal tersebut dapat mengakibatkan produktivitas petani bisa menurun dan mengakibatkan penurunan sumber penghasilan bagi keluarganya.

\section{Metode}

Penelitian ini menggunakan disain studi "cross sectional", menggunakan sumber data sekunder hasil pemeriksaan aktivitas kholinesterase darah yang dilakukan oleh Dinas Kesehatan Kabupaten Majalengka tahun 2007 dan data primer perilaku petani penyemprot hama tanaman holtikultura yang berkaitan dengan variabel-variabel penelitian. Penelitian dilakukan di 10 Desa di 5 Kecamatan di Kabupaten Majalengka, meliputi Desa Argalingga dan Argamukti di Kecamatan Argapura, Desa Girimulya dan Sunia di Kecamatan Banjaran, Desa Ketrahayu di Kecamatan Talaga, Desa Kancana, Desa Jagasari dan Desa Cisoka di Kecamatan Cikijing, serta Desa Lemah Putih dan Desa Borogojol di Kecamatan Lemah Sugih. Desa-desa tersebut merupakan daerah pertanian penghasil sayuran/holtikultura terbesar di dataran tinggi semi pegunungan. Populasi adalah petani penyemprot hama tanaman holtikultura pengguna pestisida. Sampel adalah 208 petani penyemprot hama tanaman holtikultura yang dilakukan pemeriksaan aktivitas kholinesterase darah. Penelitin ini menggunakan sumber data sekunder hasil pemeriksaan aktivitas kholinesterase darah yang dilakukan oleh Dinas Kesehatan Kabupaten Majalengka, Jawa barat pada tahun 2007.

Variabel terikat yang diamati dalam penelitian ini adalah aktivitas kholinesterase darah yang diukur dengan
Tabel 1. Distribusi Responden Menurut Hasil Pemeriksaan Aktifitas Kholinesterase Darah

\begin{tabular}{cll}
\hline Aktivitas Kholinesterase & $\mathbf{N}$ & $\%$ \\
\hline $50 \%$ & 6 & 2,9 \\
$62,5 \%$ & 43 & 20,7 \\
$75,0 \%$ & 7 & 3,4 \\
$87,5 \%$ & 67 & 32,2 \\
$100 \%$ & 85 & 40,9 \\
\hline Total & 208 & 100,0 \\
\hline
\end{tabular}

Tabel 2. Distribusi Responden Menurut Karakteristik Individu

\begin{tabular}{llll}
\hline Variabel & Katagori & N & $\%$ \\
\hline Jenis kelamin & Laki-laki & 195 & 93,8 \\
Satus gizi & Normal & 170 & 81,7 \\
Tingkat pendidikan & SD & 160 & 76,9 \\
Pelatihan/penyuluhan & Pernah & 118 & 56,7 \\
Perokok & Ya & 159 & 76,4 \\
Membeli pestisida & Ya & 196 & 94,2 \\
Lama menyemprot & $\geq 3$ jam & 118 & 56,7 \\
Waktu menyemprot & Pagi & 119 & 85,7 \\
Frekuensi menyemprot & $\leq 2$ kali/ mg & 182 & 87,5 \\
Posisi menyemprot & Membelakangi angin & 118 & 56,7 \\
Cuci tangan & Selalu & 197 & 94,7 \\
Merokok saat menyemprot & Tidak pernah & 178 & 85,6 \\
Mandi air mengalir & Salah & 197 & 94,7 \\
Terakhir menyemprot & $<14$ hari & 146 & 70,2 \\
Topi pelindung & Pakai & 188 & 90,4 \\
Sarung tangan & Tidak & 176 & 84,1 \\
Pelindung mata & Tidak & 203 & 97,6 \\
Masker & Tidak & 165 & 79,2 \\
Baju lengan panjang & Ya & 192 & 92,3 \\
Celana panjang & Ya & 185 & 88,9 \\
Sepatu boot & Tidak & 114 & 54,8 \\
& & & \\
& & &
\end{tabular}

alat Tintometer Kit Lovibond, 2000 yang sebelumnya dilakukan kalibrasi. Variabel independen dikumpulkan dengan wawancara terstruktur menggunakan instrumen khusus yang dirancang untuk penelitian ini. Pengumpulan data dilakukan oleh peneliti dibantu oleh staf Dinas Kesehatan Kabupaten Majalengka, bidang Kesehatan Lingkungan dan peneliti, sedangkan variabel bebas adalah karakteristik individu yang meliputi jenis kelamin, umur, pendidikan, pelatihan/penyuluhan, perilaku bekerja petani dan perilaku penggunaan alat pelindung diri.

\section{Hasil}

\section{Analisis Univariat}

Penelitian ini menemukan prevalensi kasus keracunan $(26,9 \%)$, dengan aktivitas kholinesterase terendah $50 \%$ $(2,9 \%)$ tertinggi $100 \%(40,9 \%)$. Dengan standar deviasi (SD $15,4 \%$ ) dan 95\% estimasi interval $83,8-88,0 \%$ ). (Lihat Tabel 1)

Distribusi frekuensi karakteristik individu yang meliputi jenis kelamin terbanyak adalah laki-laki (195; 93,8\%). Umur terbanyak < 45,22 tahun $(109,52,4 \%)$, > 
Tabel 3. Hasi Analisis Bivariat

\begin{tabular}{lll}
\hline Variabel & Katagori & Nilai p \\
\hline Umur & > mean (45 th) & 0,77 \\
Jenis kelamin & Perempuan & 0,24 \\
Satus gizi & Kurang & 0,63 \\
Tingkat pendidikan & Rendah & 0,47 \\
Pelatihan/penyuluhan & Belum pernah & 0,01 \\
Perokok & Ya & 0,50 \\
Membeli pestisida & Membeli sendiri & 0,04 \\
Jenis kemasan & Eceran & 0,56 \\
Lama menyemprot & $>3$ jam & 0,23 \\
Waktu menyemprot & Siang \& sore & 0,56 \\
Frekuensi menyemprot & $>2$ kali / mg & 0,63 \\
Posisi menyemprot & Menghadap Angin & 0,00 \\
Cuci tangan & Selalu & 1,00 \\
Merokok saat menyemprot & Selalu & 0,00 \\
Mandi air mengalir & Tidak/ kadang & 0,15 \\
Terakhir menyemprot & $<10$ hr & 0,00 \\
Topi pelindung & Tidak Memakai & 0,60 \\
Sarung tangan & Tidak Memakai & 0,05 \\
Pelindung mata & Tidak memakai & 0,33 \\
Masker & Tidak Memakai & 0,01 \\
Baju lengan panjang & Tidak memakai & 0,00 \\
Celana panjang & Tidak memakai & 0,32 \\
Sepatu boot & Tidak memakai & 0,14 \\
\hline & &
\end{tabular}

45,22 tahun $(99,47,6 \%)$. Indeks masa tubuh (IMT) kurus $(26 ; 12,5 \%)$ dan gemuk $(12 ; 5,8 \%)$. Pendidikan terbanyak tamatan SD $(138 ; 66,3 \%)$, tamat SLTP (31; $14,9 \%)$, tidak tamat SD $(22 ; 10,6 \%)$, SLTA $(15 ; 7,2 \%)$ dan PT $(2 ; 1,0 \%)$. Responden pernah menerima pelatihan/penyuluhan $(118 ; 56,7 \%)$. Berdasarkan faktor perilaku responden yang biasa membeli pestisida $(94,2 \%)$, membeli pestisida dengan kemasan asli $(72,6 \%)$, dan membeli dengan eceran $(27,4 \%)$. Responden perokok $(76,4 \%)$, responden yang menyemprot $1-2$ jam $(43,3 \%)$, $>4$ jam $(16,3 \%)$. Menyemprot $\leq 2$ kali/minggu $(87,5 \%)$ dan sering $(12,5 \%)$. Kebiasaan menyemprot pagi $(95,7 \%)$, sore $(2,9 \%)$ dan siang $(1,4 \%)$. Posisi menyemprot tidak pernah menghadap arah angin $(56,7 \%)$, dan selalu menghadap arah datang angin $(1,9 \%)$. Kebiasaan cuci tangan sebelum makan setelah menyemprot $(94,7 \%)$, kadang-kadang $(4,3 \%)$ dan tidak pernah (1\%). Tidak pernah merokok saat menyemprot $(85,6 \%)$, dan selalu merokok saat menyemprot $(1,4 \%)$. Selalu mencuci badan dan alat pada air mengalir $(94,7 \%)$. Terakhir menyemprot responden $\leq 3$ hari $(41,8 \%)$, > 10 hari $(29,8 \%)$ dan $4-10$ hari $(28,4 \%)$. Memakai topi pelindung $(90,4 \%)$, tidak memakai kaos sarung $(84,1 \%)$ tidak memakai kaca mata googel $(97,6 \%)$, tidak memakai masker $(79,3 \%)$. Memakai baju lengan panjang $(92,3 \%)$, memakai celana panjang $(88,9 \%)$, memakai sepatu boot $(45,2 \%)$. (Lihat Tabel 2 )

\section{Analisis Bivariat}

Dari analisis bivariat terlihat bahwa variabel yang memenuhi kriteria kandidat model (nilai p uni statistik Chi Square) meliputi pelatihan/penyuluhan, membeli pestisida, lama menyemprot, posisi menyemprot, merokok saat menyemprot, mandi air mengalir, terakhir menyemprot, sarung tangan, masker, baju lengan panjang sepatu boot. (Lihat Tabel 3)

\section{Analisis Multivariat}

Analisis multivariat dalam penelitian ini menggunakan analisis regresi logistik, yaitu menghubungkan beberapa variabel independen dengan variabel dependen secara bersamaan. Tujuannya untuk mencari variabel yang dominan. Selanjutnya dilakukan seleksi pada variabel yang masuk dalam model dengan analisis bivariat regresi logistik. Menurut Mickey dan Greenland dalam Murti, ${ }^{2}$ untuk menentukan variabel yang masuk kandidat adalah variabel yang memiliki kemaknaan statistik $\mathrm{p}<0,25$ maksudnya untuk memberi peluang pada variabel-variabel terselubung padahal sesungguhnya penting untuk dimasukkan ke dalam model multivariat. ${ }^{2}$ Hasil pemilihan analisis bivariat pada karakteristik individu, karakteristik pekerjaan (perilaku) dan penggunaan alat pelindung diri (APD) menunjukkan bahwa ada 14 kovariat (independen potensial) yang masuk dalam kandidat analisis multivariat $(\mathrm{p}<0,25)$ yaitu usia, jenis kelamin, pelatihan/penyuluhan, membeli pestisida sendiri, lama menyemprot, posisi menyemprot terhadap arah datangnya angin, merokok saat menyemprot, cara cuci badan/alat, terakhir menyemprot, pakai kaos sarung tangan, pakai pelindung mata, pakai masker, pakai baju lengan panjang, pakai sepatu boot. Kovariat yang dominan terhadap aktivitas kholinesterase.

Setelah dilaksanakan penyeleksian secara kemaknaan statistik, yang tidak bermakna dikeluarkan satu persatu maka diperoleh hasil berikut: Ada 7 variabel yang yang disertakan dalam model multivariat akhir mandi di air mengalir, riwayat menyemprot terakhir memakai baju lengan panjang mandi waktu menyemprot pengalaman latihan, posisi menyemprot terhadap arah angin. (Lihat Tabel 4)

\section{Pembahasan \\ Aktifitas Kholinesterase dalam Darah}

Responden dengan katagori keracunan 56 orang, sehingga didapatkan angka prevalen keracunan adalah $26,9 \%$ yang tergolong rendah jika dibandingkan dengan hasil pemeriksaan sebelumnya tahun $2005(57,8 \%), 1$ penurunan tersebut tidak sepenuhnya dijadikan indikator perbaikan program penyuluhan petani, mengingat pemeriksaan sebelumnya dilakukan pada lokasi yang berbeda. Namun, prevalen tersebut jauh lebih kecil jika dibandingkan dengan kabupaten Bandung $(40,6 \%)^{3}$ dan di Kabupaten Sambas, Kalbar (60,3\%). Besar paparan insektisida perlu dikonfirmasikan lebih lanjut dengan penelitian, karena data praeksposur diperlukan sebagai data dasar dan data hasil pemeriksaan pasca kontak 
Tabel 4. Hasil Analisis Bivariat untuk Seleksi Variabel Candidat Model Multivariat Aktivitas Kholinesterase Darah Di Kabupaten Majalengka Tahun 2007

\begin{tabular}{llll}
\hline Variabel & B & OR (Exp.B) & 95\% CI \\
\hline Umur & $-0,878$ & 0,416 & $0,190-0,911$ \\
Pelatihan/penyuluhan & 1,168 & 3,21 & $1,466-7,059$ \\
Menyemprot terhadap arah angin & 0,936 & 2,550 & $1,169-5,564$ \\
Merokok waktu nyemprot & 1,535 & 4,641 & $1,717-12,546$ \\
Mandi & 1695 & 5,446 & $1,266-23,417$ \\
Terakhir menyemprot & 2,263 & 9,613 & $2,906-31,799$ \\
Pakai baju lengan panjang & 2,183 & 8,872 & $2,006-39,232$ \\
\hline Constant & $-4,853$ & 0,008 & \\
\hline
\end{tabular}

pestisida secara rutin. Pemeriksaan sampel darah sebagai data dasar diambil ketika petani tidak sedang terpajan dengan pestisida anti kholinesterase selama sekitar 30 hari. Kolinesterase dalam plasma darah akan pulih setelah 3 minggu, sedangkan dalam sel darah 2 minggu. Untuk keakuratan hasil pemeriksaan, seharusnya pemeriksaan dilakukan pada plasma darah dan sel darah merah. Angka aktivitas kholinesterase tidak dapat dijadikan indikator efek pestisida dalam pajanan kronis karena sifatnya yang repersibel.

Berdasarkan hasil analisis multivariat logistik regresi, variabel dependen yang diamati yang berhubungan dengan aktivitas kholinesterase adalah umur, pelatihan/ penyuluhan, posisi menyemprot merokok saat menyemprot, mandi dengan air mengalir, terakhir menyemprot dan baju tangan panjang. Waktu terakhir menyemprot memperlihatkan hubungan yang paling erat dengan aktifitas kholinesterase, petani yang terakhir menyemprot $\leq$ 3 hari berhubungan 9,6 kali lebih erat daripada yang 3 hari. Hal ini terjadi akibat akumulasi pajanan pestisida secara terus menerus, sehingga organ tubuh tak dapat mensintesa enzim tersebut secara alamiah. Kholinesterase dalam plasma akan kembali normal dalam waktu tiga minggu. ${ }^{3}$ Penyemprotan arah datangnya angin $(\mathrm{OR}=2,5)$ mengakibatkan aerosol pestisida yang disemprotkan akan berbalik dan lebih banyak kontaks dengan tubuh. Jika kecepatan angin lebih dari $10 \mathrm{~km} / \mathrm{jam}$ akan terjadi turbulensi dan berpotensi mengembalikan aerosol ke tubuh penyemprot. ${ }^{4}$ Frekuensi menyemprot per minggu meningkatkan risiko keracunan karena memungkinkan peningkatkan risiko pajanan dengan insektisida dan risiko keracunan. ${ }^{3}$

Variabel lain yang berhubungan adalah tidak mandi dengan air mengalir $(\mathrm{OR}=5,4)$ akan memperkecil waktu kontak tubuh dengan insektisida. Merokok waktu menyemprot $(\mathrm{OR}=4,6)$, kemungkinan berhubungan dengan intensitas aerosol yang terhisap masuk ke paru-paru. Tidak mengikuti pelatihan/penyuluhan $(\mathrm{OR}=3,2)$. Kemungkinan berhubungan dengan pe- ngetahuan, sikap dan praktik kewaspadaan dan penggunaan alat pelindung. Seluruh variabel tersebut berhubungan dengan tingkat keterpajanan dan pengetahuan tentang risiko keracunan insektisida yang rendah. Penggunaan kain katun merupakan alat pelindung yang relatif lebih baik karena kemampuannya menyerap keringat. ${ }^{5}$ Dikatakan bahwa model pakaian pelindung yang aman untuk tenaga penyemprot adalah baju dan celana panjang, masker, topi dan sarung tangan yang mencegah memperkecil peluang kontak insektisida dengan tubuh. ${ }^{4}$

\section{Kesimpulan}

Dari 208 responden yang diteliti, sebanyak 26,9\% mempunyai aktivitas kholinesterase kategori keracunan dan selebihnya $73,1 \%$ tidak keracunan. Hasil analisis karakteristik individu yang ada hubungan bermakna dengan aktivitas kholinesterae adalah jenis kelamin $(\mathrm{p}=0,024, \mathrm{OR}=0,288,95 \% \mathrm{CI}=0,092-0,897)$, pelatihan/penyuluhan $(\mathrm{p}=0,014, \mathrm{OR}=2,161,95 \% \mathrm{CI}=1,160$ 4,026). Hasil analisis dari 11 variabel perilaku bekerja petani penyemprot yang ada hubungan bermakna dengan aktivitas kholinesterase darah adalah membeli pestisida $(\mathrm{p}=0,030, \mathrm{OR}=0,714,95 \% \mathrm{CI}=0,654-0,780)$, posisi berdiri terhadap arah datangnya angin $(\mathrm{p}=0,000$, $\mathrm{OR}=3,638,95 \% \mathrm{CI}=1,907-6,940)$, merokok saat menyemprot $(\mathrm{p}=0,000, \mathrm{OR}=6,582,95 \% \mathrm{CI}=2,881$ $15,037)$, terakhir menyemprot $(\mathrm{p}=0,000, \mathrm{OR}=8,021$, $95 \% \mathrm{CI}=2,756-23,346)$. Hasil analisis dari 7 variabel perilaku pemakaian alat pelindung diri (APD) yang ada hubungan bermakna dengan aktivitas kholinesterase darah adalah memakai kaos sarung tangan $(\mathrm{p}=0,037$, $\mathrm{OR}=3,065,95 \% \mathrm{CI}=1,026-9,157)$, memakai masker $(\mathrm{p}=0,011, \mathrm{OR}=3,400,95 \% \mathrm{CI}=1,264-9,142)$, baju lengan panjang $(\mathrm{p}=0,000, \mathrm{OR}=7,187,95 \% \mathrm{CI}=2,372$ $21,777)$. Dari penelitian ini yang dominan mempengaruhi aktivitas kholinesterase darah petani penyemprot di daerah penghasil tanaman holtikultura yang menjadi tempat penelitian adalah terakhir menyemprot 
(OR=9,613, 95\% CI=2,906-31,799), memakai APD baju lengan panjang $(\mathrm{OR}=8,872,95 \% \mathrm{CI}=2,006-39,232)$, mandi secara baik (OR=5,446, 95\% $\mathrm{CI}=1,266-23,417)$, merokok waktu menyemprot $(\mathrm{OR}=4,641,95 \%$ $\mathrm{CI}=1,717-12,546)$, pernah pelatihan/penyuluhan $(\mathrm{OR}=3,217,95 \% \mathrm{CI}=1,466-7,059)$, posisi menyemprot terhadap arah datangnya angin $(\mathrm{OR}=2,550,95 \%$ $\mathrm{CI}=1,169-5,564)$ dan umur responden ( $\mathrm{OR}=0,416,95 \%$ $\mathrm{CI}=0,190-0,911)$.

\section{Saran}

Dinas Pertanian perlu mengupayakan untuk pengaturan jadwal penyemprotan secara berkelompok, sehingga petani dimungkinkan hanya kontak 3 minggu sekali, supaya tidak terjadi akumulasi pemaparan pestisida, sehingga pembentukan kholinesterase darah dapat terbentuk secara alami. Meningkatkan pelatihan dan penyuluhan secara terpadu bagi petani penyemprot hama tanaman holtikultura tentang cara menyemprot yang baik dan benar, untuk keamanan petani dan pencegahan pencemaran lingkungan. Dinas Kesehatan Kabupaten Majalengka menyusun perencanaan pencegahan keracunan pestisida pada petani penyemprot hama tanaman holtikultura, untuk meningkatkan derajat kesehatan petani melalui peningkatan Perilaku Hidup Bersih dan Sehat (PHBS) dikalangan petani. Pemeriksaan keracunan supaya melaksanakan pemeriksaan petani sebelum musim tanam, dan sesudah musim tanam sebagai data dasar untuk perencanaan penanggulangan dan pencegahan keracunan. Pemerintah Daerah Kabupaten Majalengka memasukan perencanaan anggaran untuk mengupayakan dan intervensi pengadaan model alat pelindung diri (APD) yang dapat diterima dan sesuai untuk masyarakat petani penyemprot. Bagi peneliti lain perlu dilakukan pemeriksaan darah secara lengkap disamping pemeriksaan aktivitas kholinesterase harus disertai pemeriksaan kadar kholinesterase pula, untuk mengembangkan ilmu kesehatan masyarakat.

\section{Daftar Pustaka}

1. Dinas Kesehatan Kabupaten Majalengka, 2005, Laporan Bidang Kesehatan Lingkungan dan Promosi Kesehatan Majalengka.

2. Murti, B.,1997, Prinsip dan Methoda, Riset Epidemiologi, Gadjah Mada University Press.

3. Prabowo, K., 2002, Hubungan antara Karakteristik Individu dan Pekerjaan dengan Aktivitas Kholinesterase Darah pada Petani Pengguna Pestisida di Kabupaten Bandung Tahun 2001.

4. Nurhayati, 1997, Hubungan Model Pakaian Pelindung dengan Penurunan Kholinesterase pada Petani Penyemprot Hama Sayuran. (Tesis Program Pasca Sarjana), Depok : Fakultas Kesehatan Masyarakat Universitas Indonesia.

5. Simbolon B.H., 2004, Faktor-faktor yang Berhubungan dengan Penurunan Kadar Kholinesterase Darah Akibat Penggunaan Pestisida pada Petani Penyemprot Hama Tanaman di Kota Metro Propinsi Lampung Tahun 2004, (Tesis Program Pasca Sarjana), Depok : Fakultas Kesehatan Masyarakat Universitas Indonesia. 